\title{
150 years on: recycling the old asylums
}

\author{
Rosalind Ramsay, Registrar in Psychiatry, The Middlesex Hospital, London W1N 8AA
}

The relocation of chronic psychiatric patients in the community may be of unexpected benefit to town planners. Many Victorian mental hospitals, largely redundant in terms of medical use, are high quality buildings - some are listed or otherwise of architectural merit - and they are often set in mature landscaped grounds. Architect John Burrell has developed the idea of using former psychiatric hospital sites on the edges of cities as a basis for establishing a new urban core to outer suburban areas. His plans for the Woodford Green site won him the top prize in a national competition 'Tomorrow's New Communities', which was organised earlier this year by the Town and Country Planning Association and the Joseph Rowntree Trust, with the backing of the Prince of Wales.

Psychiatric hospitals were originally conceived as residential settlements and in his design, Burrell takes

advantage of existing amenities at Woodford Green such as the theatre, sports field, bowling green and tennis courts. In addition, primary and secondary schools, shops and health facilities are included in the plans. Although there is good public transport to the site, he is keen that it should not become a dormitory town dependent on inward commuting to the main city centres.

The architecture takes a "formal', relatively dense form, relying on a strong sense of the street as well as the diversity offered by landscaped courtyards and a variety of other urban spaces". Burrell clearly aims to avoid a diffused, low density suburban landscape, believing instead that a hospital site in a prominent position offers excellent possibilities for remaking a compact 'hill town' A further point in its favour is that the site would not impinge on green belt or viable agricultural land.

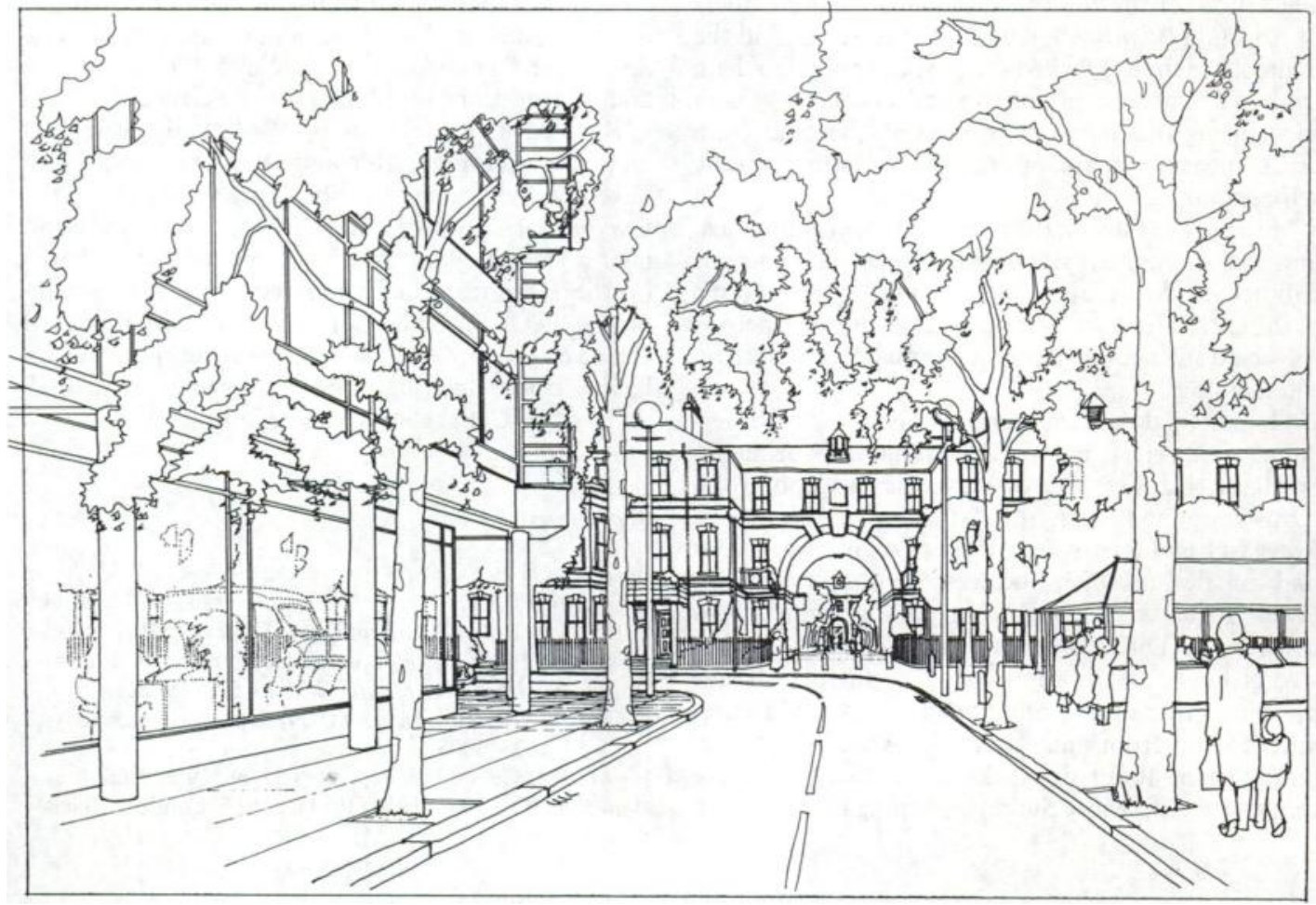

View looking south showing new route through ward block converted into flats - new buildings in the foreground provide a proper context. Courtyard landscaping beyond already exists. 
As a general principle, Burrell understands the importance of an integrated community care programme for former asylum inmates. Indeed, he hopes, some ex-patients may live in the $10 \%$ of housing designed for special needs. The remaining housing would be divided, giving $60 \%$ for families and setting $30 \%$ aside for low cost self-build homes. The site would accommodate a total of around 10,000 people. Management would be taken on by the local authority or perhaps, by a separate Community Development Trust. It is envisaged that people in the surrounding community might participate at an early stage in the planning in order to increase their chances of benefitting from new amenities within their own wider neighbourhood.

Chairman of the judging committee, Lord Vinson, praised "the universality of the scheme, its practi- cality, and the fact that it was imaginative". With mental hospitals being closed throughout England and Wales, Burrell believes his model should be applicable at up to 60 sites.

The hospital at Woodford Green is due to be decommissioned next year. The unique collection of buildings, infrastructure, woodland and landscape will be passed to an agent for disposal as a development site to the highest bidder; a reserve price of $£ 10$ million is likely. It will then be up to the Department of Health in liaison with the Department of the Environment to take the initiative and agree to pilot the award winning architect's design at the old hospital site. Burrell is not unaware of the difficulties he faces in seeing his plans to fruition. When asked what is needed, he replied, "It's called will".

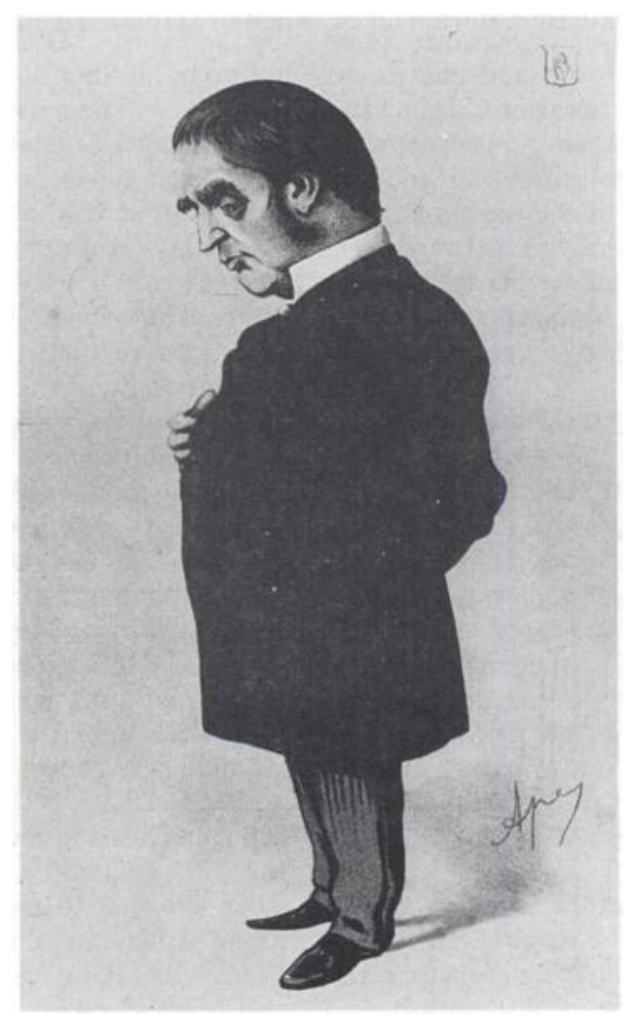

Sir William Gull (1816-1890)

Physician to the Lunatic Department at Guy's Hospital. Author of papers on anorexia nervosa. 